\title{
GENETIC EVALUATION OF THREE QUAIL LINES BY FULL DIALLEL CROSS DESIGN I-GROWTH TRAITS
}

\author{
SHeKhmou H. Hussen and JameEla H. SAlih ${ }^{*}$ \\ Dept. of Animal Production, College of Agriculture, University of Duhok, Kurdistan Region-Iraq
}

(Received: April 16, 2018; Accepted for publication: October 15, 2018)

\begin{abstract}
A total of 1307 quail chicks were hatched in two lots, from three quail lines (White-W, Light brown-Lb and Dark brown-Db). The experiment was conducted at the Poultry Farm of Animal Production Dept., College of Agriculture, University of Duhok, Kurdistan region-Iraq. The trial aimed to evaluate the genetic background of three quail lines for some productive traits by using the full diallel cross design. The following genetic parameters were estimated; general combining ability (GCA), specific combining ability (SCA), heterosis $(H \%)$, reciprocal effect $\left(R_{E}\right)$, maternal effect $\left(M_{E}\right)$, genetic value $(G V)$, heritability $\left(h^{2}\right)$ and genetic correlation $\left(r_{g}\right)$; on body weight (BW) and feed conversion ratio (FCR). The main results from the present study could be summarized as follow: GCA, SCA and $R_{E}$ showed significant differences among the studied genotypes for BW trait. All studied genotypes didn't differ significantly in $\mathrm{H} \%$ percentage and $\mathrm{M}_{\mathrm{E}}$ at 0,4 and 5 weeks old for BW trait. All studied genotypes didn't differ significantly in FCR for all studied parameters. The highest GV was recorded for $\left(\mathrm{W}^{*} \mathrm{Db}\right)$ cross. The highest $\boldsymbol{h}^{2}$ estimation $(0.76)$ was recorded for FCR in Lb line. As conclusion, it may use the $\mathrm{Lb}$ line as dam for meat production lines.
\end{abstract}

KEY WORDS: Quail, diallel cross, genetic parameters, growth traits.

\section{INTRODUCTION}

$\mathbf{T}$ The full diallel cross design often utilizes the same parents as females and males which make the design a little complicated (Isik, 2009). Mahipal, et al. (2001), used diallel cross in three quail lines and showed that the variance due to GCA was more important for body weight, but variance due to SCA was significant for reproductive traits. Analysis of combining ability for (4) meat type quails (Line1, Line2, Line3 and Line4) using diallel crosses was conducted by Drumond, et al. (2014 and 2015), they indicated significant effect for GCA on BW, while the SCA was insignificantly affecting BW. Marks, (1993a) studied the divergent selection for growth and estimated heterosis and GCA using diallel crossing for (27) generations in Japanese quail under split and complete nutritional environments. They concluded that the reciprocal effects were the greatest immediately post hatch and declined with age. Rezvannejad, et al. (2013) studied the growth characteristics in Japanese quail lines and their crosses. They reported that the reciprocal effects were significant for BW at all ages except (4) week old in males and (3) and (4) week old in females, which indicating the presence of maternal effects. Marks, (1993 b) observed that the heterosis for hatch weight was essentially zero, but heterosis percentage from pure lines ranged from 5 to $18 \%$ after one week of age. However, quail progeny from the cross were consistently larger than quail from its reciprocal cross. Amin, et al. (2013) estimated maternal effect in cross of $2 \times 2$ diallel design, using two local strains (Egg line and Meat line) with two crosses. They found that the maternal effect for BW at hatch was (0.44), and they concluded that maternal effect estimates had highly significant values and egg line was better as sire than meat line for hatch $\mathrm{BW}$, but the meat line was better for later BWs.

\section{MATERIALAND METHODS}

\section{Experimental design}

A total of 1307 (682 females and 625 males with sex ratio of $52 / 48 \%$, respectively) from one day old up to 35 days old were reared in cages as progeny flocks were used in this research, involved 9 genotypes (WW, WLb, WDb, LbW, LbLb, LbDb, DbW, DbLb, DbDb) resulted from diallel cross design for the three quail lines, White $(\mathrm{W})$, Light brown (Lb) and Dark brown (Db). 
After 35 days old, the birds redistributed as families (with sex ratio of $1 / 3$ or one male for each three females). The experiment was carried out at the Poultry Farm of Animal Production Department, College of Agriculture, University of Duhok. The experiment was conducted in order to investigate the genetic background for growth traits in the three quail lines using full diallel cross design.

The progeny flocks were hatched in two lots. Light program included 23 hours/day for the first week of age, then modified to be 15 hours/day from the second week old until the end of trial. Feed was offered ad libitum manually, which included two rations; starter $(2850 \mathrm{~K}$. cal. ME/ kg \& $26 \%$ CP) from (0-4) weeks old, and grower (2850 K. cal. ME/ $\mathrm{kg} \& 21 \% \mathrm{CP}$ ) from (4-6) weeks old (Lesson and Summers 2005).

\section{Studied parameters}

The following genetic parameters were studied for BW and FCR traits were estimated according to (Falconer, 1988 and Williams, et al. 2002) in the crosses (progeny) with avoiding sire effect:

General Combining Ability (GCA): The values of GCA for the lines were computed as the means of specific line for giving trait.

\section{$\boldsymbol{G C A} A_{i}=\Sigma \boldsymbol{y}_{i} / \boldsymbol{n}$}

Where: $\mathrm{GCA}_{\mathrm{i}}=$ the GCA for line ${ }_{\mathrm{i}}$; $\mathrm{yi}=$ trait for a progeny from the specific line ${ }_{i} \cdot n=$ the number of all progenies.

\section{Specific Combining Ability (SCA):}

The values of SCA for the crosses were computed as the difference between average of cross with its reciprocal cross and average of GCA for both lines, for given trait according to the following formula:

$S C A_{A B}=\left[(A B+B A) / 2-\left(G C A_{A}+G C A_{B}\right) / 2\right]$

Where: $\mathrm{AB}=$ the cross; $\mathrm{BA}=$ The reciprocal cross

/Heterosis (H \%): Hybrid vigor (heterosis) was computed on the basis of percentage of midparents for the given trait as following equation:

$H \%=\{F 1-[(P 1+P 2) / 2] /[(P 1+P 2) / 2] x 100\}$

Where $\mathrm{F} 1=$ mean of the first generation and $(\mathrm{P} 1$ and P2) are the parents in diallel cross design.

Reciprocal Effect $\left(\mathbf{R}_{\mathrm{E}}\right)$ : Reciprocal effect was computed as half of the difference between the cross and its reciprocal cross for the given trait, according to the following formula:

$\boldsymbol{R}_{E}=(y j i-y i j) / 2$

Where: $y \mathrm{ji}=$ reciprocal cross; $\mathrm{yij}=$ the cross

Maternal Effect $\left(\mathbf{M}_{\mathrm{E}}\right)$ :

Maternal effect was computed as the mean deviation of progeny for a particular dam, from mean estimated for a particular sire, according to the following formula:

$M_{E}=(\bar{y} \cdot i-\vec{y})$

Where: $\bar{y} . \dot{i}=$ particular dam average; $\bar{y} \mathrm{i}=$ particular sire average.

Genetic Value (GV): Genetic value of a cross is representing the GCA of both parents and SCA of the same cross, and is calculated according to the following formula:

$G V_{(A B)}=G C A_{(A)}+G C A_{(B)}+S C A A_{(A B)}$

Heritability $\left(\mathbf{h}^{2}\right)$ : Heritability estimates were computed from the relationship between the average of the one-parent and the offspring (from regression coefficient), and from the variance components which were resulted from the effect of both GCA and SCA as random factors in ANOVA. So, it could summarize the computation of heritability as the following two equations:

$h^{2}{ }_{1}=2 b ;$ and $h_{2}^{2}=4\left(\sigma_{G C A}^{2}+\sigma_{S C A}^{2}\right) / \sigma_{P}^{2}$

$$
\boldsymbol{h}^{2}=\left(\boldsymbol{h}^{2}{ }_{1+} \boldsymbol{h}_{2}^{2}\right) / 2
$$

Where $b=$ regression coefficient of offspring on parents; $\sigma_{P}^{2}$ is a phenotypic variance of a trait, and it included additive, dominant and residual effects.

Genetic Correlation $\left(\mathbf{r}_{\mathrm{g}}\right)$ : Genetic correlations between some previous traits were calculated according to the geometric equation as follows:

$r_{g}=\sqrt{ }(\operatorname{Cov} Z 2 X 1 * \operatorname{Cov} Z 1 X 2) / \sqrt{ }(\operatorname{Cov} Z 1 X 1 *$ Cov Z2X2)

Where: $\mathrm{Z}=$ the observations on parent; $\mathrm{X}=$ the observations on offspring; $1=$ the first trait; $2=$ the second trait.

\section{Statistical analysis}

The experiment were designed as diallel cross within completely randomized design (CRD), and collected data was analysed using SAS (SAS, 2010) software via mixed model

The mixed model for the effect of GCA and SCA as random effects in addition to the fixed effects of the replication (lot) was applied to analyse the previous studied traits in order to estimate the heritability according to the following model:

$Y_{i j}=\mu+R_{i}+G C A+S C A+e_{i j}$

Where: $\mathrm{Y}_{\mathrm{ij}}$ : the observations of the studied trait; $\mu$ $=$ overall mean; $\mathrm{R}_{\mathrm{i}}$ : The fixed effect of replication; GCA: the random effect of GCA; SCA: the random effect of SCA. $\mathbf{e}_{\mathrm{ij}}$ : random error.

The differences between the means were analysed using Duncan multiple range test (Duncan, 1955). 


\section{RESULTS AND DISCUSSION}

General combining ability for body weight:

General combining ability (GCA) for BW trait is represented in table (1). It could be noticed that the GCAs are significantly different $(p<0.05)$ among the three studied lines just at ( 3 and 6$)$ weeks of age, where the $\mathrm{Db}$ line surpassed $\mathrm{W}$ one at (3) weeks old in body weight trait; while Lb line was intermediate between them, and at (6) weeks old the $\mathrm{W}$ line recorded significantly the lowest value compared to both brown lines which didn't differ significantly.

Table (1). General combining ability for body weight trait at different age.

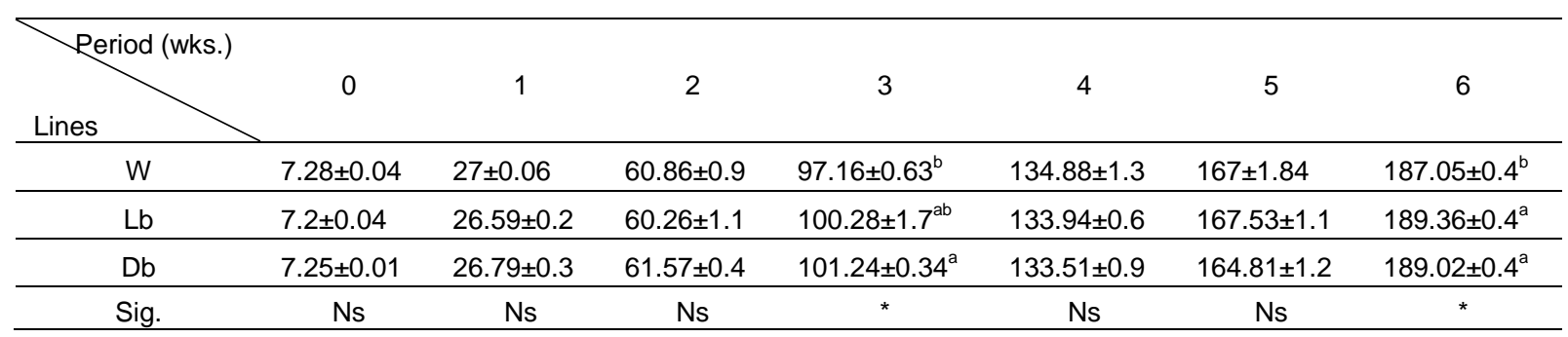

Ns= Non-significant; $*=$ significant at $(P \leq 0.05)$; values $=$ means $\pm \mathrm{SE})$. Means having different litters within each column differ significantly.

This result suggests that the critical growth period in quail changed at 3 weeks old. The both brown lines recorded higher BW (189.19 gm.) than white line $(187.05 \mathrm{gm}$.$) at (6) week old.$ However, and from these findings it could be suggested that if the breeders would like to breed quail birds for egg production, they have to breed white line and it should be culled white line in case of meat production. Similar results were found by (Razuki and Al Soudi 2005 and Mekky, et al. 2008) who mentioned that significant GCA for BW was recorded among different genotypes, and they concluded that it may obtain a good chance to select among them to improve their growth.
General combining ability for feed conversion ratio:

Figure (1), illustrating GCA values for FCR during the growth and laying periods in pure lines. There were insignificant differences among the three studied lines. Generally, during growth period the GCA appeared to be the best in Lb line and worst in $\mathrm{Db}$ line, while $\mathrm{W}$ line was intermediate. The opposite was true for laying period, where $\mathrm{Db}$ achieved the best value and $\mathrm{Lb}$ recorded the worst value, and $\mathrm{W}$ remained as intermediate.

These findings showed that the growth in quail has critical periods which changes FCR genetically. While at sexual maturity and then at egg production periods the curves are reversed to illustrate the best value in GCA for FCR of $\mathrm{Db}$ line and the worst value was for Lb line. Contrary to the present result, (Adebambo, 2011) reported significant GCA for feed efficiency using four chicken breeds. 


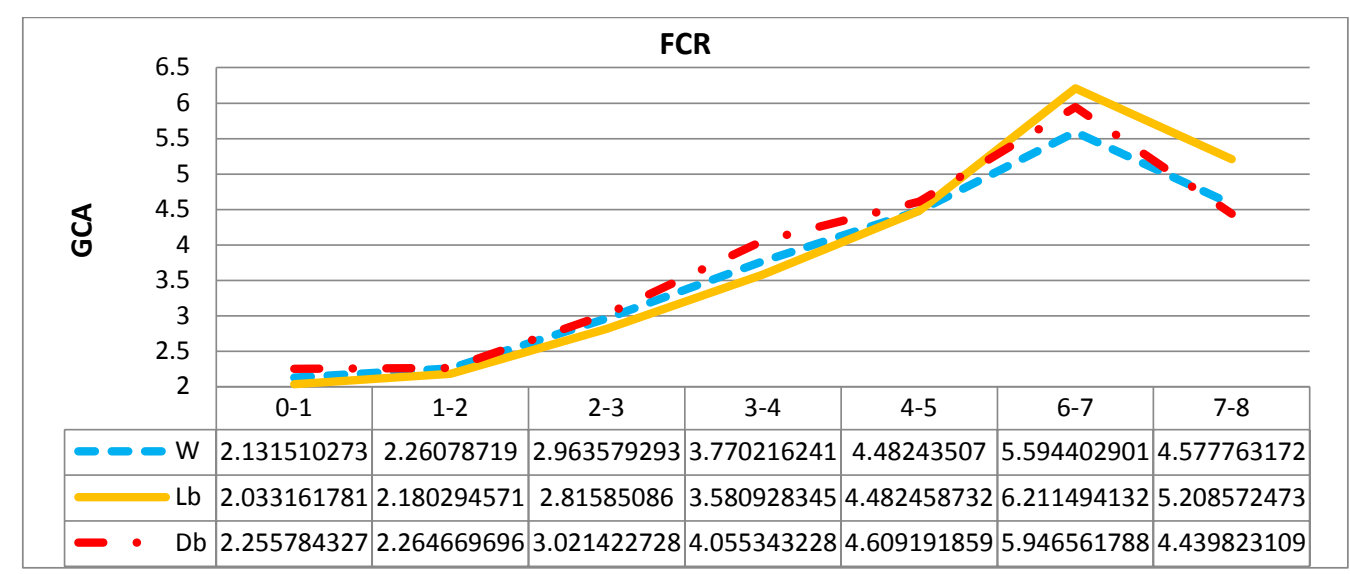

Fig. (1). General combining ability for feed conversion ratio at growth and laying period (weeks)

\section{Specific combining ability for body weight:}

The SCA of BW at different ages is presented in table (2). The crosses didn't show an obvious trend for BW trait as affected by non-additive gene action (dominance and epistasis) which representing the SCA. However, the cross $\left(\mathrm{W}^{*} \mathrm{Lb}\right)$ surpassed significantly $(P<0.05)$ the other two crosses at 0 and 4 weeks old, which illustrate heavier weight from the genetic interaction. While $\left(\mathrm{W}^{*} \mathrm{Db}\right)$ cross reflected the superiority at 2 and 6 weeks of age for BW as being affected by the genetic

interaction.

Table (2). Specific combining ability for body weight trait in the crosses during the period from 0-6 weeks of age.

\begin{tabular}{cccccccc}
\hline $\begin{array}{c}\text { Period (wks } \\
\text { Cross }\end{array}$ & 0 & 1 & 2 & 3 & 4 & 5 & 6 \\
\hline$W^{*} \mathrm{Lb}$ & $0.11 \pm 0.25^{\mathrm{a}}$ & $-0.47 \pm 0.2$ & $-1.24 \pm 0.5^{\mathrm{b}}$ & $1.51 \pm 2.18$ & $0.72 \pm 0.82^{\mathrm{a}}$ & $1.34 \pm 0.52$ & $-3.95 \pm 0.1^{\mathrm{b}}$ \\
\hline $\mathrm{W}^{*} \mathrm{Db}$ & $0.01 \pm 0.04^{\mathrm{ab}}$ & $0.28 \pm 0.42$ & $0.85 \pm 0.81^{\mathrm{a}}$ & $3.37 \pm 0.29$ & $-0.25 \pm 0.1^{\mathrm{ab}}$ & 0.181 .45 & $1.42 \pm 2.35^{\mathrm{a}}$ \\
\hline $\mathrm{Lb} \mathrm{Db}$ & $-0.13 \pm 0.07^{\mathrm{b}}$ & $-0.02 \pm 0.1$ & $0.17 \pm 0.08^{\mathrm{ab}}$ & $-0.17 \pm 1.1$ & $-1.37 \pm 0.03^{\mathrm{b}}$ & $0.14 \pm 0.58$ & $1.31 \pm 0.41^{\mathrm{a}}$ \\
\hline Sig. & $*$ & $\mathrm{Ns}$ & $*$ & $\mathrm{Ns}$ & * $^{*}$ & $\mathrm{Ns}$ & $*$ \\
\hline
\end{tabular}

Ns = Non-significant; $*$ =significant at $(P \leq 0.05)$; values = means \pm SE). Means having different litters within each column differ significantly

Moreover, the cross $(\mathrm{Lb} * \mathrm{Db})$ recorded the intermediate interaction for BW trait. This result indicates that both brown lines of quail are less interacted genetically to increase BW, which may due to the resemblance relative between them, while white line shows to be interacted genetically with both brown lines, which may be return to the crossbreeding. The present findings are in agreement with the results found by (Mohamed, et al. 2005) who reported significant SCA for body weight among crossbreed groups during different ages. The non-additive genetic effects (SCA) being involved in the inheritance of body weight was also reported by (Shebl, et al. 1990). Many reports showed that general combining ability (additive genetic effects) were high and important as well as specific combining ability (non-additive effects that involve dominance and epitasis) for body weight at different ages (Mohamed, et al. 2005; Amin, 2007; Mekky, et al. 2008; El-
Bayomi, et al. 2009; Razuki and AL-Shaheen, 2011 and Lalev, et al. 2014).

\section{Specific combining ability for feed conversion ratio:}

The SCA values for the FCR of studied crosses are represented in figure (2). It can be noticed from the curves that $\left(\mathrm{W}^{*} \mathrm{Lb}\right)$ cross tend to decrease the FCR during the growth period and increasing it during the laying period. While the cross $(\mathrm{Lb} * \mathrm{Db})$ play a reverse role.

However, the cross $\left(\mathrm{W}^{*} \mathrm{Db}\right)$ didn't have any genetic interaction for FCR trait. These results indicated that it may use the Lb line as dam in case of meat production and as sire in case of egg production to reduce FCR trait. Contrary to the present results (Adebambo, 2011) reported significant SCA for FCR using four chicken breeds. (Razuki and Al- Shaheen, 2011) found that at sexual maturity age, SCA estimates were negative for FCR trait. 


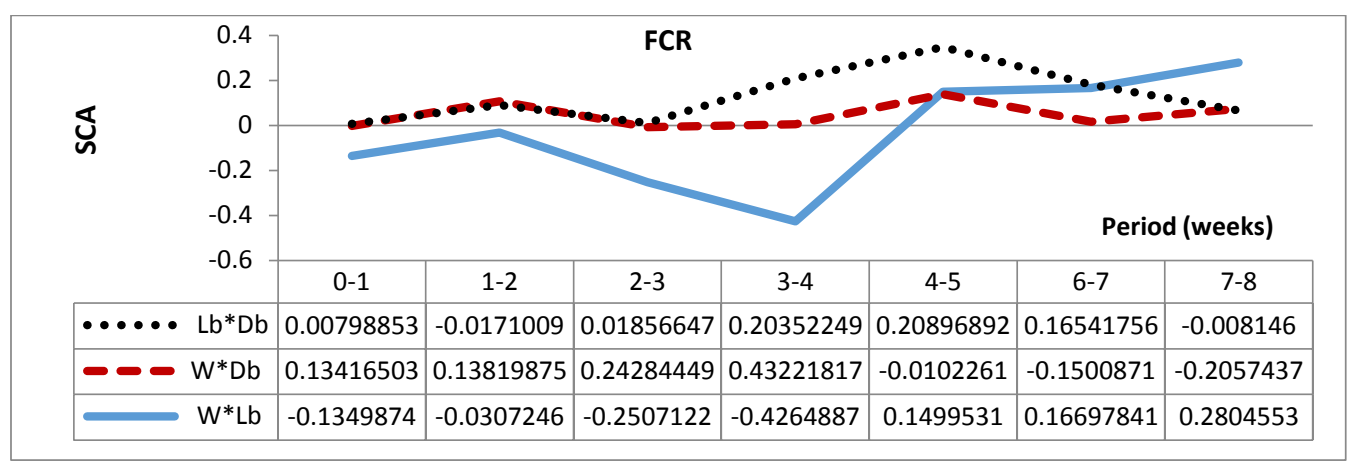

Fig. (2). Specific combining ability for feed conversion ratio of the crosses during growth and laying periods.

\section{Heterosis for body weight:}

The results of BW heterosis\% are presented in figure (3), all genotypes didn't differ significantly. It can be noticed that all genotypes are positive except $\mathrm{Lb}^{*} \mathrm{Db}$ cross at the beginning of growth period. Then all genotypes (except $\mathrm{Lb} * \mathrm{~W}$ reciprocal cross) had the same trend as fluctuation of curves in order to delay (become negative) followed by rising negative percentages during the next periods of growth up to the final studied period (5 weeks old) except the cross $\left(\mathrm{W}^{*} \mathrm{Lb}\right)$ which was positive with small value at (5) weeks of age $(1.97 \%)$.

Hanafi and Iraqi (2001) found similar results in chickens, they mentioned non-significant heterotic effects on body weight at 8 weeks of age.
Contrary by, the present results are in disagreement with the findings that reported were by (Iraqi, et al. 2002) who indicated that heterosis percentage estimates were generally positive and high for body weights of crossbreds obtained from crossing between Mandarah and Matrouh strains of chickens. However, most reviewed studies showed that body weights at different ages of crossbred chickens were associated with positive heterotic effects for growth traits (Sabri and Hataba, 1994; Khalil et al. 1999; Sabri, et al. 2000). Theoretically, the magnitude of heterosis is inversely related to the degree of genetic resemblance between parental population Willham and Pollak

(1985).

\begin{tabular}{|c|c|c|c|c|c|c|}
\hline \multirow[t]{2}{*}{$\begin{array}{r}5 \\
0 \\
-5 \\
-10 \\
-15 \\
-20 \\
-25 \\
-30\end{array}$} & \multicolumn{4}{|c|}{ BW } & \multicolumn{2}{|c|}{ Periods (wks.) } \\
\hline & 0 & 1 & 2 & 3 & 4 & 5 \\
\hline$\cdots \cdots W^{*} \mathrm{Lb}$ & 3.350382293 & -15.73 & -11.25 & -6.15 & -5.98 & 1.97 \\
\hline $\mathrm{W}^{*} \mathrm{Db}$ & 0.78 & -9.88 & -11.41 & -4.78 & -6.41 & -1.93 \\
\hline $\mathrm{Db} * \mathrm{Lb}$ & 2.59 & -20.67 & -16.66 & -13.24 & -12.2 & -3.23 \\
\hline $\mathrm{Lb} * \mathrm{~W}$ & 5.19 & -18.1 & -22.08 & -11.49 & -8.28 & -1.79 \\
\hline - $\mathrm{Db}^{*} \mathrm{~W}$ & 2.94 & -25.31 & -16.660514 & -10.82 & -9.82 & -2.04 \\
\hline$---\mathrm{Lb}^{*} \mathrm{Db}$ & -3.58 & -19.62 & -14.78 & -7.15 & -7.15 & -0.71 \\
\hline
\end{tabular}

Fig. (3). Heterosis percentage for body weight during growth periods (0-5 wks.) of old.

\section{Heterosis for feed conversion ratio:}

Heterosis percentages for FCR are illustrated in figure (4). All genotypes had positive percentages at the beginning period of growth. Then it decrease gradually to record negative percentages for all genotypes except the reciprocal cross $(\mathrm{Db} * \mathrm{~W})$ and the cross $(\mathrm{W} * \mathrm{Db})$ during $(2-3)$ and (3-4 weeks) of age, respectively. Where the both mentioned genotypes were recording positive percentages. 


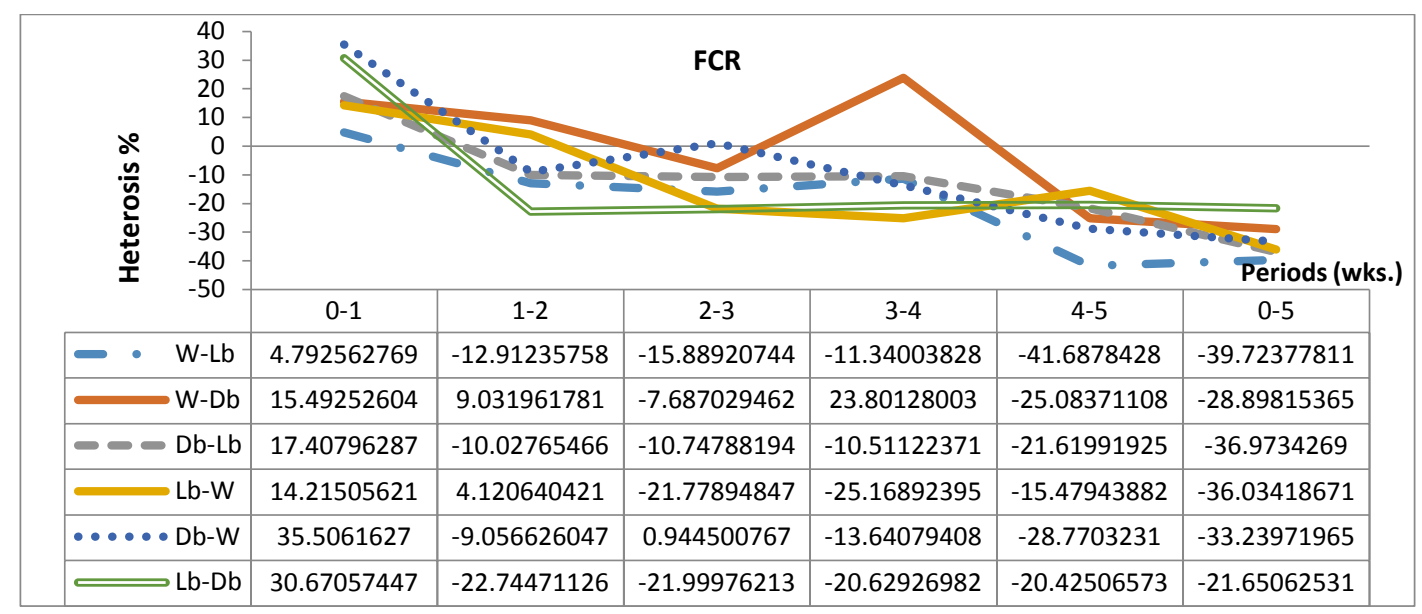

Fig. (4). Heterosis percentage for feed conversion ratio for cross and reciprocal cross at growth periods.

However, all genotypes recorded negative heterosis percentages during the final growth periods ( $0-5$ weeks.), which represent the average heterosis percentage, and it was ranged almost from $(-20 \%$ to $-40 \%)$. These results indicate that the most crosses tend to improve the FCR as affected by diallel crosses. The present results were similar to results founded by (Youssao, et al., 2009) who stated that there was a negative heterosis effect for feed efficiency of the different genotypes.

\section{Reciprocal effect on body weight:}

The results of reciprocal effect on BW were presented in table (3). The results showed significant $(\mathrm{p}<0.05)$ reciprocal effect one which were recorded at first two weeks of age. While in other periods, all genotypes didn't differ significantly.
It could be noticed that $\left(\mathrm{Db}^{*} \mathrm{Lb}\right)$ reciprocal cross has recorded the highest values $(0.27$ and $0.35 \mathrm{gm})$ in the first and second week of age, respectively. These results insure that $\mathrm{Db}$ sires interacted with $\mathrm{Lb}$ 's dams in order to increase BW in the progenies. While, $\mathrm{W}$ dams prevent both $\mathrm{Db}$ and $\mathrm{Lb}$ sires to increase $\mathrm{BW}$ in the next generation. However, the strength of $\mathrm{Lb}$ sires were less than $\mathrm{Db}$ The present results are in agreement with that found by (Jakubec, et al. 1987; Vitek, et al. 1994 and Razuki \& AL-Shaheen, 2011) in respect to the significant effect of reciprocal crosses on BW at earlier ages of growth, and the present results were disagreement with the findings of (Gerken and Zimmer, 1988) who reported non-significant effects of reciprocal cross on body weight trait.

Table (3). Reciprocal effect on body weight trait during growth periods

\begin{tabular}{|c|c|c|c|c|}
\hline \multirow{2}{*}{ Period(wks) } & \multicolumn{3}{|c|}{ Reciprocal crosses } & \multirow{2}{*}{ Sig. } \\
\hline & Lb*W & $\mathrm{Db}^{*} \mathrm{~W}$ & $\mathrm{Db}^{*} \mathrm{Lb}$ & \\
\hline 0 & $0.07 \pm 0.02^{b}$ & $0.06 \pm 0.06^{b}$ & $0.27 \pm 0.05^{\mathrm{a}}$ & * \\
\hline 1 & $-0.38 \pm 0.42^{\mathrm{ab}}$ & $-2.23 \pm 0.91^{b}$ & $0.35 \pm 0.06^{\mathrm{a}}$ & * \\
\hline 2 & $-3.86 \pm 1.1$ & $-1.67 \pm 2.17$ & $0.44 \pm 0.11$ & Ns \\
\hline 3 & $-2.94 \pm 0.11$ & $-2.68 \pm 1.14$ & $-3.34 \pm 0.67$ & Ns \\
\hline 4 & $-1.68 \pm 1.57$ & $-1.81 \pm 1.85$ & $-2.13 \pm 1.05$ & Ns \\
\hline 5 & $-3.17 \pm 1.37$ & $0.10 \pm 1.72$ & $-1.14 \pm 1.02$ & Ns \\
\hline
\end{tabular}

$\mathrm{Ns}=$ Non-significant; *=significant at $(P \leq 0.05)$; values = means \pm SE. Means having different litters within each row differ significantly.

Reciprocal effect on feed conversion ratio:

Reciprocal effect on FCR shows insignificant differences among the three reciprocal crosses during growth periods figure (5). It could be noticed the same previous trend effect on FCR, where the $\mathrm{Db}$ sires tried to improve FCR via increasing weight gain in spite of the fluctuation in the curves (positive and negative values). However, Lb sires didn't interact with $\mathrm{W}$ dams to improve FCR. 


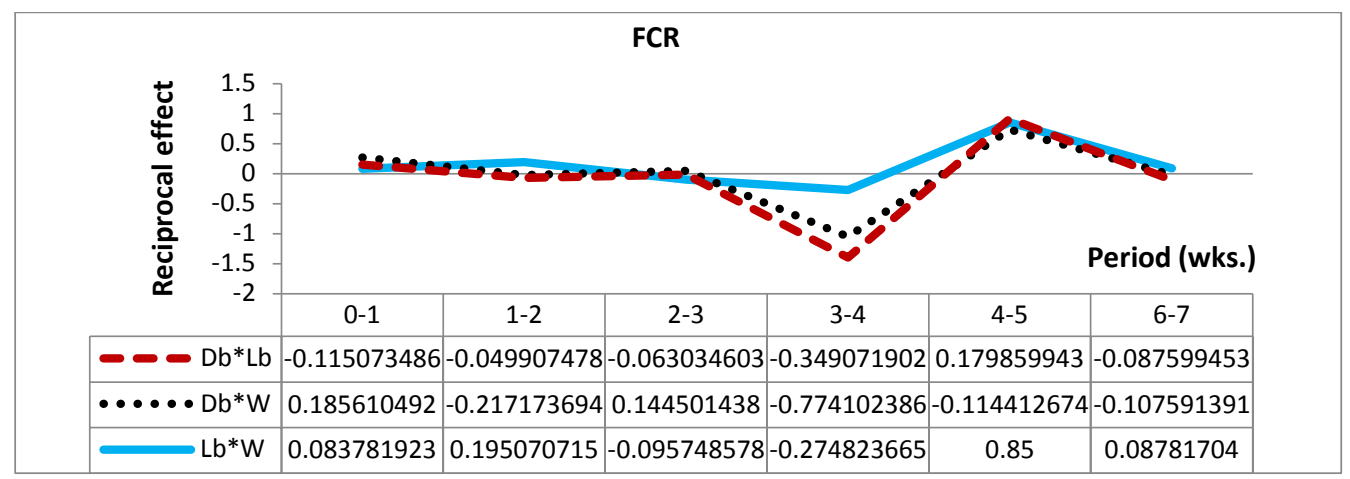

Fig. (5). Reciprocal effect for FCR at growth periods.

The present findings are similar to the results that were found by Amin (2015) who reported insignificant reciprocal effects on feed conversion ratio.

\section{Maternal effect on body weight:}

Table (4) showed the maternal effect (ME) on BW trait during the growth period from $(0-5$ wks.). There were insignificant differences among the three studied lines at $(0,4$ and 5 weeks $)$ old. While, ME was significant $(\mathrm{P}<0.05)$ at one week old and highly significant $(\mathrm{P}<0.01)$ at $(2$ and 3 weeks) of age. However, the highest positive ME values were recorded in Lb line $(0.25,2.57$ and
$1.96 \mathrm{gm})$ at (1, 2 and 3 weeks of age), respectively.

These results may indicate the intermediate BW of Lb line compared to other lines. The present findings are in disagreement partially with the results obtained by (Abd El-Hamed, et al.2004 and Nofal, 2005) who reported that the ME of BW traits was not significant. On the other hand, these results are in agreement partially with the results mentioned by (Mekky, et al. 2008 and Razuki \& AL-Shaheen, 2011) who found that estimation of maternal effect for BW were significant.

Table (4). Maternal effect for body weight during (growth period).

\begin{tabular}{|c|c|c|c|c|c|c|}
\hline $\begin{array}{l}\text { Reriod(wks.) } \\
\text { Line }\end{array}$ & 0 & 1 & 2 & 3 & 4 & 5 \\
\hline W & $0.09 \pm 0.06$ & $-1.73 \pm 0.33^{b}$ & $-3.68 \pm 0.68^{b}$ & $-3.74 \pm 0.69^{b}$ & $-2.32 \pm 2.28$ & $-2.05 \pm 2.06$ \\
\hline $\mathrm{Db}$ & $0.04 \pm 0.08$ & $-1.58 \pm 0.41^{b}$ & $-3.47 \pm 0.79^{b}$ & $-4.47 \pm 0.27^{b}$ & $-2.42 \pm 2.23$ & $-1.84 \pm 2.18$ \\
\hline $\mathrm{Lb}$ & $-0.04 \pm 0.02$ & $0.25 \pm 0.28^{a}$ & $2.57 \pm 0.77^{a}$ & $1.96 \pm 0.07^{\mathrm{a}}$ & $1.17 \pm 1.05$ & $2.11 \pm 0.92$ \\
\hline Sig. & Ns & * & $* *$ & ** & Ns & Ns \\
\hline
\end{tabular}

different litters within each column differ significantly.

\section{Maternal effect for feed conversion ratio:}

Maternal effects of FCR are illustrated in figure (6). $\mathrm{M}_{\mathrm{E}}$ for FCR was not differing significantly at all studied periods, but showed fluctuations in curves of both $\mathrm{W}$ and $\mathrm{Db}$ lines at all studied periods. However, $\mathrm{W}$ and Db lines had positive and negative values at different studied periods, respectively. While Lb line appeared to be zero in its influence at the same studied periods. Moreover, the highest positive value of ME was recorded for the line $\mathrm{W}(0.49)$ during the growth period, while the lowest negative value of ME was recorded for the line $\mathrm{Db}(-1.07)$ during the laying period. 


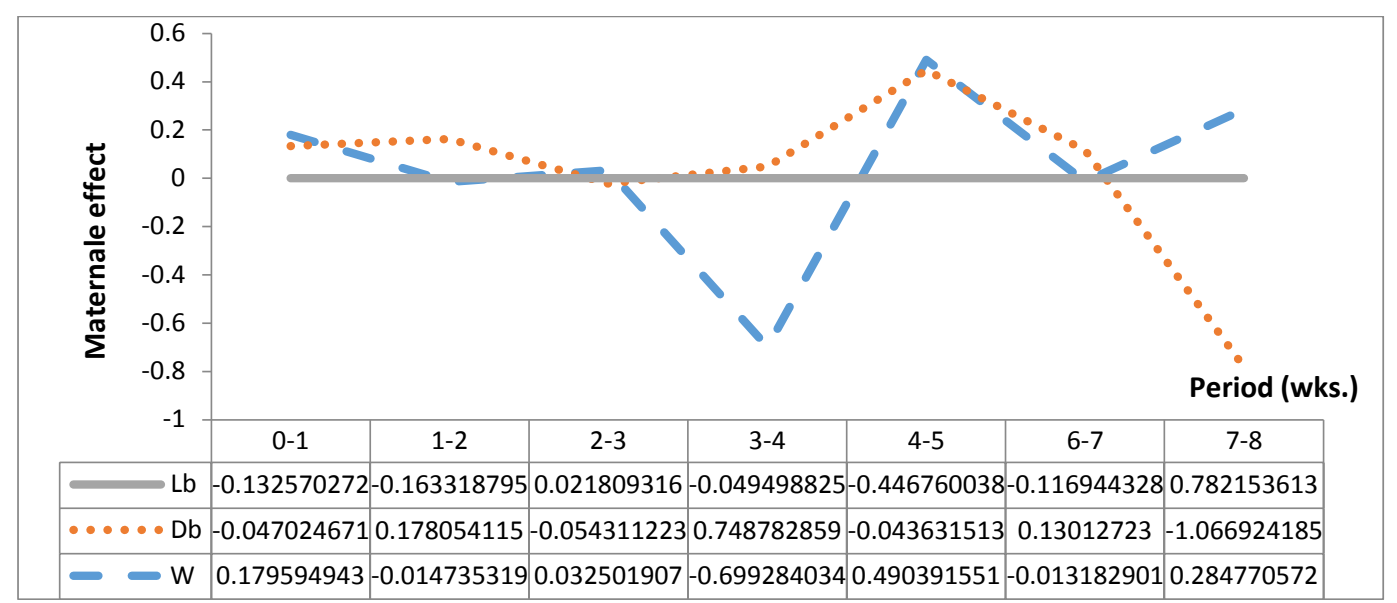

Fig. (6). Maternal effect of feed conversion ratio during trail periods.

These results may indicate that it could improve FCR by using $\mathrm{Db}$ line as dams in crossing programs. The present results were similar to the results obtained by (Abdel-Hamed, et al. 2004 and Nofal, 2005) who reported not significant maternal effects for all growth traits (including FCR).

\section{Genetic value for body weight:}

Table (5) presented the genetic values of BW of the crosses in the studied growth periods. There were insignificant differences among the three crosses for all the studied periods. The highest genetic values at (1,2 and 3) weeks of age, were recorded for $\mathrm{W}^{*} \mathrm{Db}$ cross as $(27.22,62.34$ and $100.89 \mathrm{gm})$ respectively. While, the highest GV's at $(0$ and 4$)$ weeks old were recorded for $\mathrm{W}^{*} \mathrm{Lb}$ cross (7.34 and $135.22 \mathrm{gm}$., respectively).
However, the final growth period resulted in the best GV's with (168.26 gm) for Lb* Db cross. Moreover, the non-significant differences among the studied crosses indicated that the genetic values of the parents and their crosses are similar. In another word it could be say that the inheritance of BW in quail isn't affected by both additive and non-additive factors. The findings reported by (Amin, 2015), there was disagreement with the present results, He mentioned significant positive GV's for the crosses of BW trait. While (Razuki and AL-Shaheen, 2011) recorded negative significant genetic effect on BW in chickens crosses. (Vitek, et al. 1994) found that the genetic value on BW was significant.

Table (5). Genetic value for body weight during the growth period.

\begin{tabular}{ccccccc}
\hline Reriod(wks) & 0 & 1 & 2 & 3 & 4 & 5 \\
\hline Cross & & & & & \\
W*Lb & $7.34 \pm 0.1$ & $26.27 \pm 0.1$ & $58.95 \pm 2.54$ & $98.07 \pm 3.27$ & $135.22 \pm 1.02$ & $172.54 \pm 3.75$ \\
\hline $\mathrm{W}^{*} \mathrm{Db}$ & $7.29 \pm 0.08$ & $27.22 \pm 0.01$ & $62.34 \pm 0.54$ & $100.89 \pm 0.02$ & $133.82 \pm 2.35$ & $167.77 \pm 1.57$ \\
\hline $\mathrm{Lb}{ }^{*} \mathrm{Db}$ & $7.1 \pm 0.05$ & $26.31 \pm 0.56$ & $60.12 \pm 1.05$ & $98.98 \pm 0.11$ & $131.25 \pm 1.24$ & $168.26 \pm 3.68$ \\
\hline $\mathrm{Sig}$ & $\mathrm{Ns}$ & $\mathrm{Ns}$ & $\mathrm{Ns}$ & $\mathrm{Ns}$ & $\mathrm{Ns}$ & $\mathrm{Ns}$ \\
\hline
\end{tabular}

Ns $=$ Non-significant; values $=$ means \pm SE

\section{Genetic value for feed conversion ratio:}

Figure (7) presented the genetic value of FCR, and illustrating non-significant differences among the studied crosses. The highest genetic value at the first week of age was recorded for $\mathrm{W} * \mathrm{Db}$ cross
(2.45), and the lowest genetic value for FCR was recorded for $\mathrm{W}^{*} \mathrm{Lb}$ cross (2.19). However the $\mathrm{Lb} * \mathrm{Db}$ cross (2.21) was intermediate between them. Then it increased gradually until the final studied growth period (4-5 weeks.). 


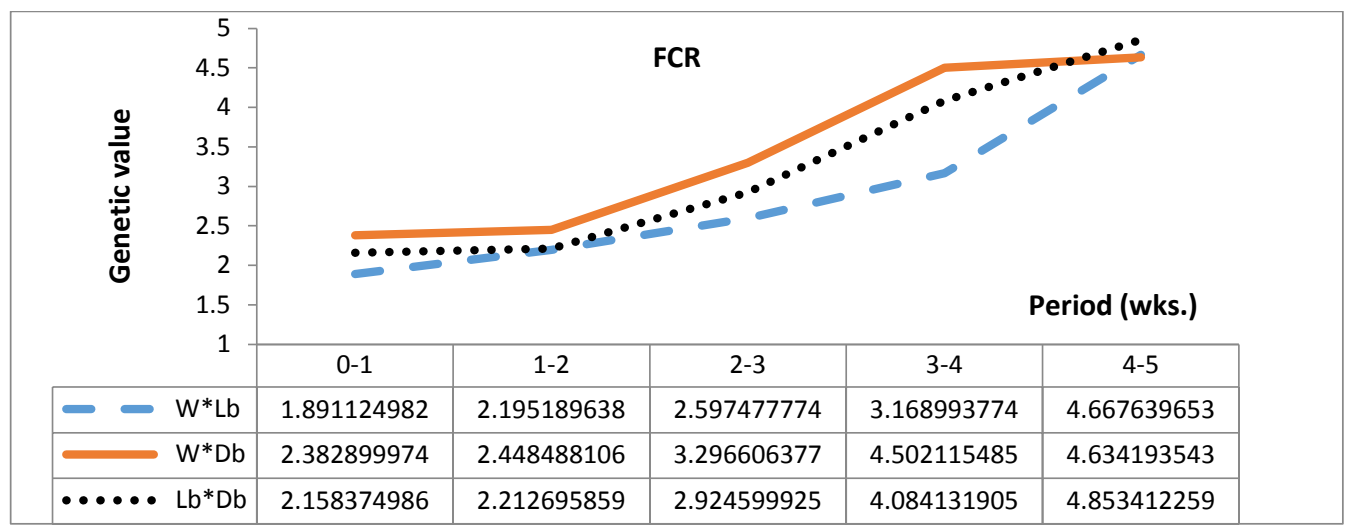

Fig. (7). Genetic value for feed conversion ratio during growth period.

The last result indicates that $\mathrm{Db}$ dam play a role to increase the FCR in the progeny. These results were disagreement with the findings that reported by (Amin, 2015), he recorded small GVs for FCR, which were between (-0.21- 0.08).

\section{Heritability and genetic correlation:}

The heritability, genetic correlation and phenotypic correlation coefficients within each studied line are represented in Table (6). In respect to heritability, which estimated directly from the relationship between parent and offspring, and indirectly from the ranom effects of both GCA and SCA, the results showed that the highest estimation values were recorded for FCR (0.76) in $\mathrm{Lb}$ and FCR (0.59) in $\mathrm{W}$ line. While Lb line appeared the effective growth performance, because it considers the moderate line between $\mathrm{W}$ and $\mathrm{Db}$ lines for growth productive performance. However, realized heritability estimations for BW and FCR of J. quail during growth period were $(0.78)$ and (0.77) respectively (Hussen et al. 2016 a). Generally, (Berwary et al.2015) found that heritability estimation for BW and FCR were (0.47 and 0.62$)$ respectively, in J. quail birds.

Regarding to genetic correlation estimation (Table 6), the results show that the correlation coefficients between BW and FCR were positive and relatively high in both $\mathrm{W}$ and Lb lines (0.39 and 0.48 , respectively), while the same estimation in $\mathrm{Db}$ line was negative $(-0.40)$. This result may reflect the meat type for $\mathrm{Db}$ line.

Table (6). Heritability, genetic correlation and phenotypic correlation coefficients for growth traits within studied quail lines.

\begin{tabular}{rccc}
\hline Traits & Line & $\mathrm{BW}_{42 \text { day }}$ & $\mathrm{FCR}_{\text {growth }}$ \\
\hline \multirow{2}{*}{$\mathrm{BW}$} & $\mathrm{W}$ & $\mathbf{0 . 2 3}$ & 0.37 \\
\cline { 2 - 4 } 42 day & $\mathrm{Lb}$ & $\mathbf{N E}$ & $-0.79^{*}$ \\
\cline { 2 - 4 } & $\mathrm{Db}$ & $\mathbf{0 . 1 9}$ & -0.44 \\
\hline \multirow{2}{*}{ FCR $_{\text {gr }}$\begin{tabular}{c} 
owth \\
\cline { 2 - 4 }
\end{tabular}} & $\mathrm{W}$ & 0.39 & $\mathbf{0 . 5 9}$ \\
\cline { 2 - 4 } & $\mathrm{Lb}$ & 0.48 & $\mathbf{0 . 7 6}$ \\
\cline { 2 - 4 } & $\mathrm{Db}$ & -0.4 & $\mathbf{0 . 2 2}$ \\
\hline
\end{tabular}

Heritability on the diagonal, phenotypic correlation above the diagonal and genetic correlation coefficients bellows the diagonal. $*=$ significant at $(P \leq 0.05) ; \mathrm{NE}=$ Non-estimated

The genetic correlation coefficients between BW and FCR were moderate (negative for $\mathrm{Db}$ and positive for both $\mathrm{W}$ and $\mathrm{Lb}$ lines. The present results disagree with that wich was found by (Mielenz et al. 2006) in the Japanese quail. The genetic correlation between BW and FCR during growth period for Japanese Quail was similar to the present result and estimated as (0.45) (Hussen et al. 2016 a), its mean that the FI was higher. ///With regard to the growth period in Japanese quail, the phenotypic correlation coefficient between BW and FCR was computed as -0.28 (Hussen, et al. 2016 b).

\section{CONCLUSION}

As conclusion from all the previous results, it could be use White line as sire and light brown line as dam, because of its relatively efficient 
genetic parameters. The selection programs may apply for FCR, because it has high heritability estimation.

\section{REFERENCES}

- Abd El-Hamed HS, Torkey HA, AL Shaboury FA, Sleim MMA, Ellakany \& Awad AM (2004). Epidemiological studies on Salmonellosis in poultry. The $4^{\text {th }}$ Sci. Conf., 2- $4^{\text {th }}$ Oct. Fac. Med. Alex. Univ., Egypt.

- Adebambo AO (2011). Combining abilities among four breeds of chicken for feed efficiency variation: a preliminary assessment for chicken improvement in Nigeria, Tropical Animal Health and Production; 43 (8): 1465-1466.

- Amin EM (2007). Effect of crossing on growth performance and viability of commercial and native Egyptian chicken breeds. Egypt. Poult. Sci; 27 (IV): 1151-1173.

- Amin EM, Kosba MA, El- Dlebshany AE \& ElNgomy MA (2013). Heterosis, maternal and direct additive effects for growth traits in the Alexandria chickens. Egypt. Poult. Sci; 33: 1033-1051.

- Amin EM (2015). Genetic components and heterotic effect of .diallel crossing experiment in chickens. J Am Sci; 11(1): 62-77. (ISSN: 15451003).

- Berwary MS, Oramari RA \& Hussen SH (2015). Correlated response to selection for residual feed intake in Japanese quail (Coturnix coturnix japonica). Journal of University of Duhok; 18(1): Pp 135-144.

- Drumond ESC, Pires AV, Bonafe CM, Pinheiro SRF, Veloso RC, Amaral JM \& Abreu LRA (2014). Egg laying and egg quality in meat type quails in diallel crosses. Genet. Mol. Res; 13 (4): 81188125.

- Drumond ESC, Pires AV, Veloso RC, Bonafe CM, Pereira IG, Costa LS, Abreu LRA (2015). Performance of meat type quails in diallel cross. Arq. Bras. Med. Vet. Zootec; 67 (1): 235-241.

- Duncan DB (1955). Multiple range and multiple F tests. Biometrics; 11: 1-42.

- El-Bayomi MKh, El-Tarabany MS \& Abdel-Hamid TM (2009). Heterosis and combing ability of some productive traits in four breeds of rabbit. Egypt. Poult. Sci; 10: 159-177.

- Falconer DS (1988). Introduction to Quantitative Genetics. Third edition, John Wiley and Sons, New York, U.S.A.

- Gerken M \& Zimmer S (1988). Juvenile body weight and gonad development in a diallel cross among lines of Japanese quail (Coturnix coturnix japonica ); 76(5): 775-780.
- Hanafi MS \& Iraqi MM (2001). Evaluation of purebreds, heterosis, combining abilities, maternal and sex-linked effects for some productive and reproductive traits in chickens. Second International Conference on Animal Prod. Health in Semi-Arid Areas, 4-6 September, Organized by Faculty of Environmental Agricultural Science, Suez Canal Unvi. El Arish-North Sinai, Egypt; pp 545-555.

- Hussen SH, Al-Khdri AMA \& Hassan AM (2016 a). Response to selection for body weight in J. quail (Coturnix coturnix japonica). Iranian Journal of Applied Animal Science (IJAS); 6(2): 453-459.

- Hussen SH, Hassan AM \& AL-Khdri AMA (2016 b). Estimation of some genetic parameters for egg quality traits in Japanese quail (Coturnix coturnix japonica). Journal of University of Duhok; 19(1): 32-37 (Special Issue).

- Iraqi MM, Hanafi MS, Khalil MH, EI-Labban AFM \& Eii-Sisy M (2002). Genetic evaluation of growth traits in crossbreeding experiment involving two local strains of chickens using multi- trait animal model. Livestock Research for Rural Dev; 14:1-7.

- Isik F (2009). Analysis of Diallel Mating Designs. First edition, North Carolina State University, Raleigh, USA.

-Jakubec V, Komender P, Nitter G, Fewson D \& Soukupova Z (1987). Crossbreeding in farm animals. Analysis of complete diallel experiments by means of three models with application to poult. J. Anim. Breed. Genet; 104: 283-294.

- Khalil MH, Hermes IH \& AI-Homidan AH (1999). Estimation of heterotic components for growth and liveability traits in a crossbreeding experiment of Saudi chickens with White Leghorn Egyptian Poult. Sci; 19: 491-507.

-Lalev M, Mincheva N, Oblakova M, Hristakieva P \& Ivanova I (2014). Estimation of heterosis, direct and maternal additive effects from crossbreeding experiment involving two White Plymouth Rock lines of chickens. Biotechnology in Animal Husbandry; 30 (1): 103-114.

- Lesson S \& Summers JD (2005). Commercial Poultry Nutrition, 3rd edition, University books, P. O. Box. 1326, Guelph, Ontario, Canada ISBN 9781-904761-78-5.

- Mahipal RP, Venkateshwarlu YP, Prasad VL, Eshwaraiah K, Ravinder RV (2001). Combining ability analysis of a diallel cross involving three quail lines for production traits. Indian Journal of Poult. Sci. Volume: 36, Issue; 2: 147-152. 
- Marks HL (1993 a). Carcass composition, feed intake and feed efficiency following long- term selection four week body weight in Japanese quail. Poul. Sci; 72: 1005-1011.

- Marks HL (1993 b). Divergent selection for growth in Japanese quail under split and complete nutritional environments. 6. Differential body weights in reciprocal crosses, (in press as cited by Marks, 1993 a).

-Mekky SS, Galal A, Zaky HI \& Zein-EI-Dein A (2008). Diallel crossing analysis for body weight and egg production traits of two native Egyptian and two exotic chicken breeds. Int. J. Poult. Sci; 7: 64-71.

-Mielenz N, Ronny R \& Schuler L (2006). Estimation of additive and non-additive genetic variances of body weight, egg weight and egg production for quails (Coturnix coturnix japonica) with an animal model analysis. Arch. Tierz; 49: 300307.

- Mohamed MD, Abdalsalam YI, Kheir ARM, Jin-yu W \& Hussein MH (2005). Growth performance of indigenous $\mathrm{x}$ exotic crosses of chicken and evaluation of general combining ability under Sudan condition. Poult. Sci; 4 (7): 468- 471.

- Nofal RY (2005). Crossbreeding parameters of females in two lines of Japanese quail for some growth and sexual maturity traits. Egypt. Poult. Sci; 26 (I): (69- 85).

- Razuki WM \& Al-Soudi KA (2005). Combining ability and gene action to various strains of broiler parents.1.Body weight. The Iraqi J. Agric. Sci; 36: 123-132 (In Arabic).

- Razuki WM \& AL-Shaheen SA (2011). Use of full diallel cross to estimate crossbreeding effects in laying chickens. International Journal of Poult. Sci; 10 (3): 197-204.

- Rezvannejad E, PAKDEL A, Miraee Ashtianee SR, Mehrabani Yaganeh SR \& Yaghoobi MM
(2013). Analysis of growth characteristics in short-term divergently selected Japanese quail lines and their cross. The Journal of Applied Poultry Researchjapr.oxfordjournals.org J Appl Poult. Res; 22 (4): 663-670.

- Sabri HM \& Hataba NA (1994). Genetic studies on some economical traits of some local chicken breeds and their crosses.1. Growth and viability.Egypt.J.Appi.Sci; 9: 949-963.

- Sabri HM, Khattab MS \& Abdel-Ghany AM (2000). Genetic analysis for body weight traits of a diallel crossing involving Rhode Island Red, White Leghorn, Fayoumi and Dandarawi Chickens. Annals of Agricultural Science Moshtohor; 38: 1869-1883.

- SAS Institute (2010). SAS User's Guide, Ver. 9.1: Statistics. SAS Institute Inc., Cary, NC.

- Shebl MK, Ali MA, Balat MM \& Tag El- Din TH (1990). Evaluation of combining ability for some body size traits and feathering in a diallel cross of chickens. Egypt. Poult. Sci; 10: 159177.

- Vitek M, Wolf J, Soukupova Z, Tyller M \& Jakubec V (1994). Diallel analysis in laying hens. Arch. Geflügelk; 58: 278-284.

- Willham RL \& Pollak E (1985).Theory of Heterosis.J. Dairy Sci; 68: 2411-2417.

- Williams, SM, Price SE \& Siegel PB (2002). Heterosis of growth and reproductive traits in fowl. Poult. Sci; 81:1109-1112.

-Youssao IAK, Senou M, Dahouda M, Kpodékon MT, Djenontin J, Idrissou ND, Bonou GA, Tougan UP, et.al. (2009). Genetic improvement of local chickens by crossing with the label rouge (T55XSA51): Growth Performances and Heterosis Effects. International Journal of Poult. $\begin{array}{llll}\text { Sci; } & 8 & (6): & 536-544 .\end{array}$ 


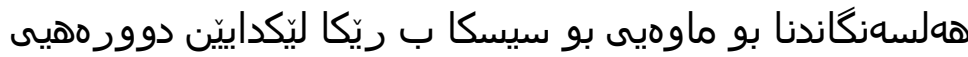

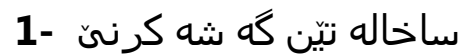

يوخته

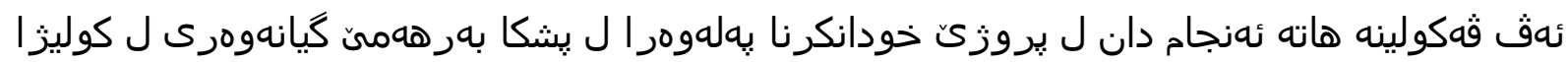
جاندنى زانكويا دهوك. دقى ثهكولينى دا(

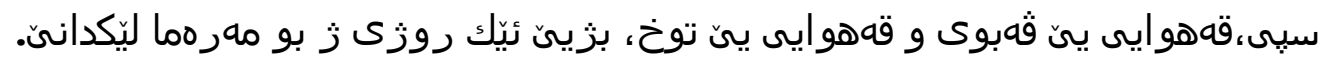

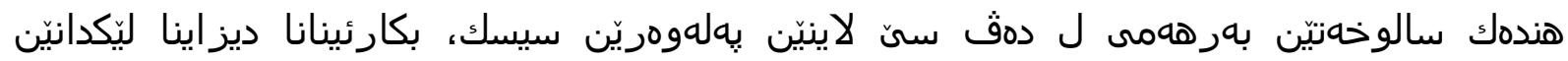

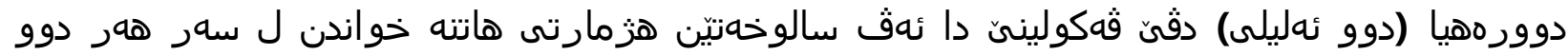

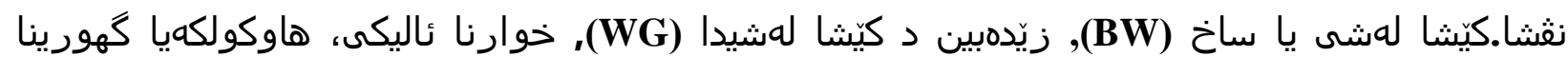

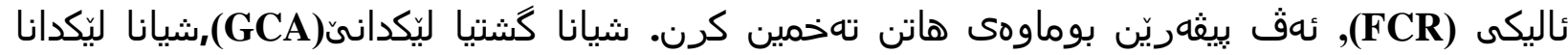

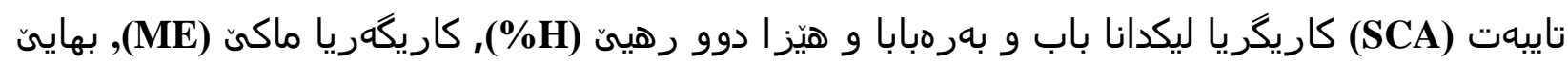

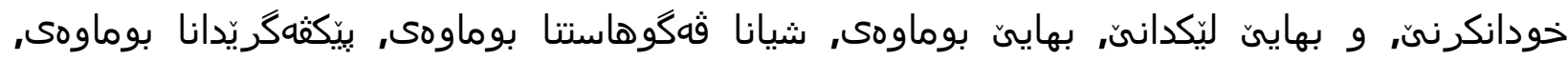

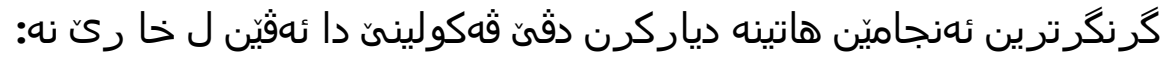

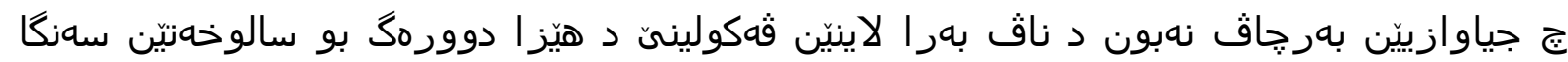

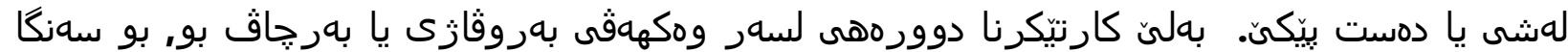

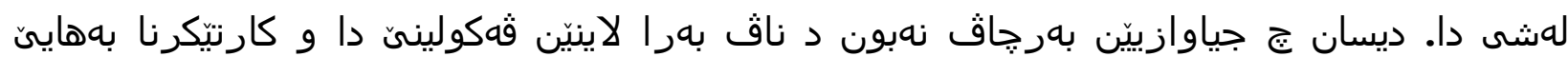

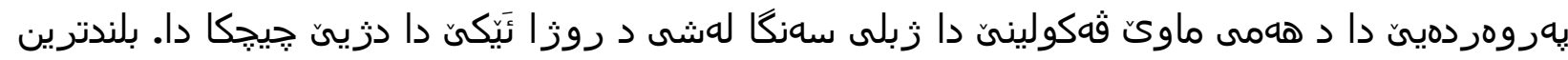
بهاينّ بو ماوهيى هاته توماركرن بو دوورههين (سيى*توخ) بلندترين هاوكولكهين بو ماونين داوهيى هاته

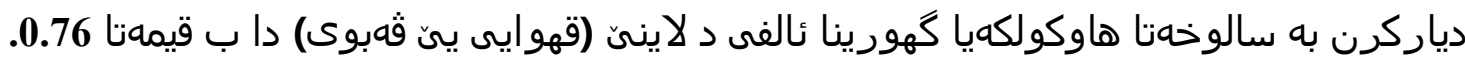

\section{التقييم الوراثية للسمان باستخدام التهجين ثنائي الأليل الكامل

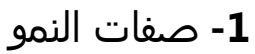

الخلاصة

تم فقس عدد 1307 صوصاً على دفعتين من ثلاثة خطوط للسمان الياباني (الأبيض والبني الفاتح والبني

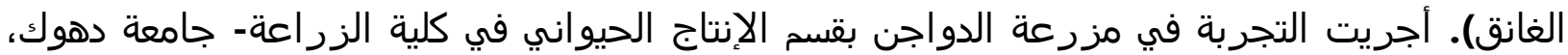

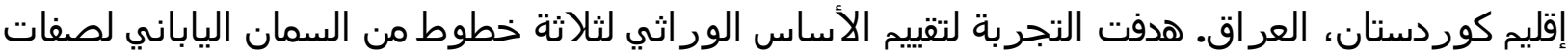

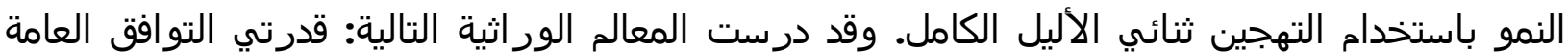

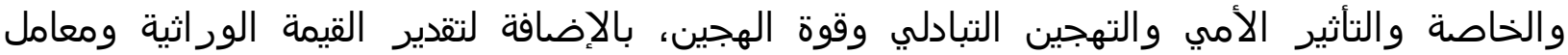

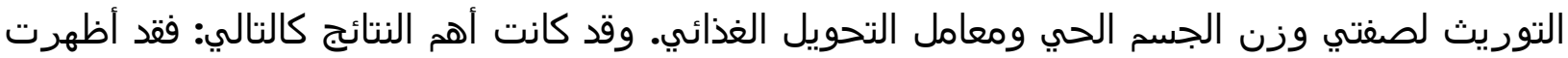

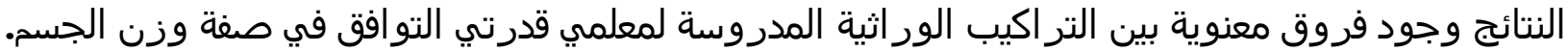

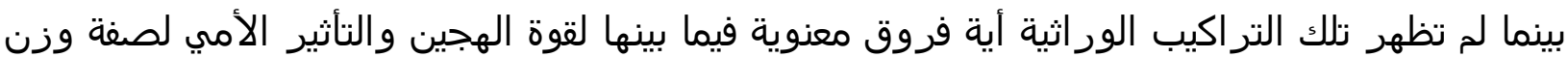

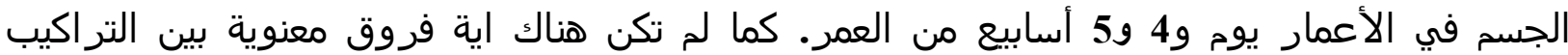

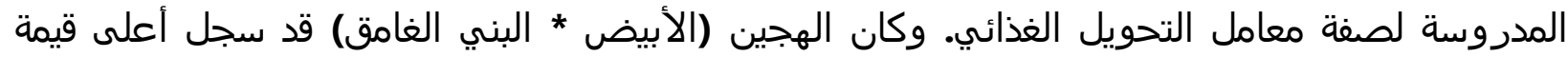

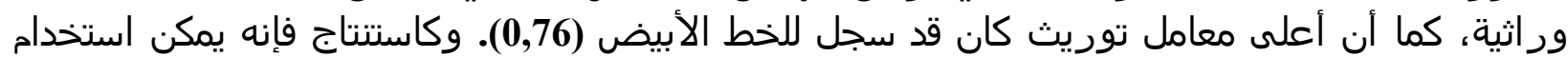

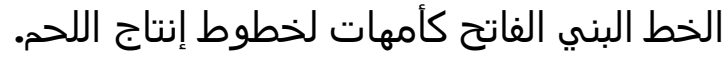

